\title{
A MODEL OF A TACIT KNOWLEDGE TRANSFORMATION FOR THE SERVICE DEPART- MENT IN A MANUFACTURING COMPANY: A CASE STUDY
}

\author{
Adam DUDEK*, Justyna PATALAS-MALISZEWSKA** \\ *University of Applied Science in Nysa, Institute of Computer Science, Poland \\ e-mail: adam.dudek@pwsz.nysa.pl \\ **University of Zielona Góra, Institute of Computer Science and Production Management, \\ Zielona Góra, Poland \\ e-mail: j.patalas@iizp.uz.zgora.pl
}

\begin{abstract}
This article elaborates on the development of a dedicated model of a tacit knowledge transformation for the service department in a manufacturing company. The four main components of the tacit knowledge transformation process are formulated: (1) tacit knowledge source identification, (2) tacit knowledge acquisition, (3) tacit knowledge determination and formalization, and (4) knowledge classification. The proposed model is illustrated by examples on the use of the methods: automatic recognition of speech, natural language processing, and automatic object recognition in the tacit knowledge transformation process in order to obtain a formalized procedure for the service department in a manufacturing company. This is followed by a discussion of the results of the research experiments.
\end{abstract}

Keywords: case study, tacit knowledge transformation process, automatic recognition of spoken, natural language processing, automatic object recognition, manufacturing company.

\section{$1 \quad$ Introduction}

The knowledge management process in companies is now becoming one of the key processes determining the achievement of competitive advantage in the market. This knowledge is procedural in nature ("know how") or declarative ("know what") (Piotrowska, 2012). Alternatively, it is also possible to distinguish between explicit and/or tacit knowledge in a company. Explicit knowledge usually takes a structured form; the process of explicit knowledge management is currently supported by Information and Communications Technology (ICT), for example, data warehouses, CRM systems, electronic data interchange systems - Electronic Data Interchange (EDI) or Enterprise Resource Planning (ERP) (Kwasek, 2016). Tacit knowledge is most frequently identified with company employees.

Tacit knowledge is claimed to be the main asset of the company, and therefore, businesses should seek to develop and implement procedures that will allow to carry out the process of converting tacit knowledge into explicit knowledge. The process of conversion comprises the following steps: (1) identification of the sources of tacit knowledge,
(2) the acquisition of tacit knowledge, (3) a formal recording of tacit knowledge, and (4) the classification of the acquired knowledge. This article undertakes the problem of designing and implementing a model of converting tacit knowledge into explicit knowledge in the service department in a manufacturing company. The data comprise sources of tacit knowledge in the service department, as well as acquired knowledge hidden from these sources. On the other hand, at our disposal are the methods of converting tacit knowledge into explicit knowledge, for example, the technology of automatic speech recognition (ASR), the technology of natural language processing (NLP), and the technology of automatic object recognition (AOR). The answer to the following question is sought after: Is there among the considered methods supporting the conversion of tacit knowledge into explicit knowledge such one whose application guarantees, at a specific time, obtaining a formalized procedure based on tacit knowledge in the service department of a manufacturing company?

The purpose of this article is, therefore, to introduce the concept of a model converting tacit knowledge into explicit knowledge in the service department of a manufacturing company and to present the re- 
search experiments using the method of automatic voice recognition as a means of obtaining a formalized procedure for customer service in the company.

\section{The methods for tacit knowledge transformation - theoretical background}

To characterize the processes of an explicit and a tacit knowledge acquisition, the concept of the so-called spiral of knowledge (Nonaka, Takeuchi, 2000) can be applied, whereby the cycle is represented by the following processes: socialization of tacit knowledge, its externalization to non-formal explicit variety, codifying and sharing the newly created explicit knowledge, and internalization, that is, the acquisition of new knowledge by employees. The basis of this cycle is the distribution of tacit knowledge between individuals, and its transformation into an explicit form - processes that are fundamental for the field of knowledge acquisition (KA). It is a multidisciplinary and dynamic field of science, whose most important stages are acquisition of knowledge from a human expert, interpretation of the acquired knowledge, and constructing a model of knowledge (Boose, 1989).

Two levels of defining tacit knowledge are worth noticing. This is clearly emphasized by (Faust, 2007), whereby the author indicates a tacit knowledge so obvious to the holders that they find it unnecessary to disclose, and a knowledge rooted in practice, experience, beliefs, and intuition, but expressed in the professionalism and practical skills. While in the first case, the revealed gap in knowledge can be easily captured by the recipient, for whom this knowledge is not obvious; in the second case, the problem lies in the difficulty to grasp the essence of this knowledge, and thus effectively indicate the method of acquiring it.

The analysis of literature (Ali, Peebles, 2013; Lemke, 2012; Govaerts, 2012; Salamon, et al., 2012; Hoffman, et al., 1995; Seager, et al., 2011; Antonova and Stefanov, 2011; Gourova, et al., 2012; Pa, et al., 2012; Ragsdell, et al., 2013; Yusoff and Salim, 2012; Zielinski, 2015; Potocki and Lukasik, 2014; Lesnik and Dobrowolski, 2016) allows to distinguish the following methods of acquiring tacit knowledge: a real-time teacher observation, the analysis of prob- lem-solving procedures (verbal and non-verbal communication), training sessions, courses, demonstrations, auditing knowledge, hidden interviews, problem simulations in virtual reality (phenomena and processes simulators (Karkula, 2014; Gałaj, Oleksy, 2013), application games (Allal-Chérif, et al., 2016; Boyle, et al., 2016), augmented reality (Dzwiarek and Luczak, 2008; Gonzales-Franco, et al., 2016; Lin, et al., 2013).

The process of KA may be either explicit and direct in character (conducting training) or implicit (observation, monitoring, imitation) (Wyrębek, 2013), and its effectiveness is dependent on both the techniques used and the creation of such mechanisms within the corporation that allow developing trust between employees, thus increasing their willingness to share knowledge, experience, and skills (Ziółkowski, 2015).

However, the introduction of a well-tailored motivational system for sharing knowledge in the organization will not suffice for effective externalization of tacit knowledge. In situations where employees will additionally be required to record their knowledge, a natural resilience will occur resulting from the necessity of an extra workload that they would have to perform. It is, therefore, recommended to use such solutions that would automate the process of extraction and transformation of tacit knowledge, thus engaging the employees in a minimum measure.

In the manufacturing company considered here, the acquisition of tacit knowledge from the employees of the service department is based on the method of teacher observation and the simultaneous audit of knowledge. In order to carry research experiments, the process of performing the selected tasks by the service personnel has been recorded using audio-video and then analyzed. This approach allowed the employees to perform standard tasks without engaging them in other duties.

For the purpose of designing and carrying out the procedure of converting the acquired tacit knowledge, the technology of ASR was applied. Initially, the solutions for the ASR class were restricted to individual sounds or syllables (Davis, et al., 1952; Furui, 2005). Intensive development of these techniques eventually allowed to recognize 
whole words, and then strings. The key stages included: the use of LPC (linear predictive coding) (Itakura, 1975; Gomółka, 2008; Grad, 2007; Kale and Ghabad, 2015), the use of Markov's hidden chains (HMM) (Rabiner, Juang, 1993; Mietła and Iwaniec, 2010; Shomali, et al., 1999; Przybysz, Kasprzak, 2012; Kompanec, Kubanek, 2002), statistical n-gram models (Jelinek, 1985), dynamic Bayesian network (Zweig and Russel, 1998; Mermon, 2011), or neural networks (Hinton, et al., 2012). By using the so-called speech corpora, the ASR class systems recognize sequences of words in dictated utterances more effectively (Przepiórkowski, et al., 2012). The increasing efficiency of the ASR techniques helped to introduce a number of commercial solutions also for the combination of spontaneous speech recognition in conjunction with the detection of objects in the audio-visual material, for example, voice search (Lundy, 2016) or Cisco pulse video analytics (Cisco, 2012). Unfortunately, as far as the recognition of the Polish language is concerned, only a few applications are able to recognize continuous speech: SKRYBOT (Pawlaczyk, Bosky, 2009), the Sarmata project (Żelazko, et al., 2015), or MagicScribe (MagicScribe, 2016), and the solution provided by Google called Google Speech API.

To become sources for acquiring knowledge, the documents obtained through voice recognition must be treated by the techniques known as NLP. In principle, they are used for linguistic analysis, and subsequently for the representation of texts in word processing similar to the approach used by humans. It should be noted here that in spite of the continuous development of NLP, the techniques encounter a number of problems, such as inflexion and ambiguity occurring in different languages. Two approaches are used here:

- Deep text processing: It is based on linguistic analysis of all the interpretations and collocations present in a natural text (Goth, 2016; Kambhatla, Zitouni, 2013).

- Shallow text processing: It is a statistical analysis, identifying the main parts of sentences, proper names, or noun compounds (Hernes, et al., 2015).

In the presented model of knowledge transformation, we assume the use of statistical NLP tools (Yang, Liu, 1998) and language corpora to assist in the clas- sification of the identified fragments of recordings as applicable in the pre-existing service procedures. Additionally, we assume the possibility of applying the AOR class solutions for identifying objects in the recorded material.

AOR is one of the most important aspects of computer image analysis. As a starting point, a range of solutions based on the analysis of a single input image should be indicated, including Bayesian classifiers (Boiman, et al., 2008; Li, Perona, 2005), decision trees and random forests (Bosh, et al., 2007), or geometric matching (Lazebnik, et al., 2006; Yang, et al., 2009). The aforementioned solutions contributed to the development of object recognition techniques in simultaneous recordings from multiple sources. (Christoudias, et al., 2008; Gouet-Brunet, Lameyre, 2008; Lee, Soatto, 2011).

\section{A model of a tacit knowledge transfor- mation for the service department in a manufacturing company: a model TKT-SDMC}

The proposed TKT-SDMC model consists of four elements: (1) identification of sources of tacit knowledge, (2) acquisition of tacit knowledge, (3) introduction of a formalized record of tacit knowledge, and (4) classification of the acquired knowledge. This article attempts to present the third stage of the model, that is, to carry out the conversion process of the already acquired tacit knowledge in the service department of a production company into explicit knowledge.

The service department considered in this article deals with the service inspection of manufactured products as part of scheduled maintenance, the removal of defects or abnormalities detected during these procedures, and carrying out contracted repairs that occurred during the warranty period of the product, and after its expiry date. These tasks are performed by specialists from different fields (mechanics, automatic technicians, sprayers, electricians, and others) who have both different levels of expertise and the so-called general knowledge. The experience of the manager cited in the example with the service department indicates that the tendency to formalize his knowledge depends, on the 
one hand, on the applied motivational methods, and on the other, on the level of educational background. In most cases, managers operate on the basis of pre-established service procedures.
Each procedure consists of several steps. The schematic diagram in Fig. 1 shows an example of a maintenance procedure, on whose basis the procedure of balancing a wheel mounted on a serviced vehicle is conducted.

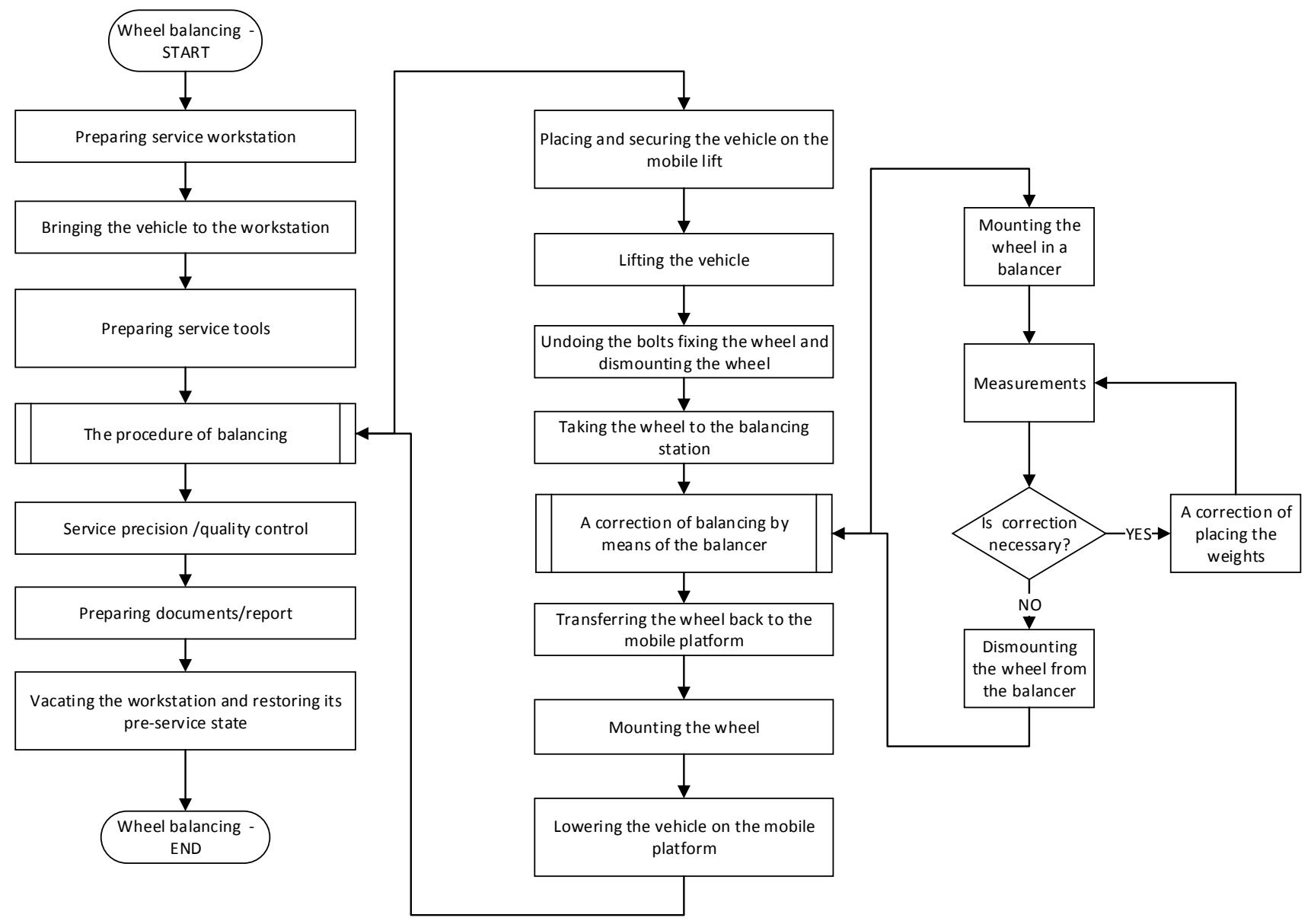

Figure 1. An example of a servicing procedure divided into action components

For the purposes of the experiment, the course of this task has been recorded and then analyzed by one of the service personnel. As a result of this analysis, one can identify the additional steps performed by the serviceman, which the procedure failed to anticipate. The diagram in Fig. 2 shows the result of this experiment, where a different color highlights those actions that needed to be performed due to technician's tacit knowledge. In the case of the action marked (1), the basis for its completion was deeply hidden expertise resulting from the technician's experience - in this case, the "loosening" of bolts before lifting the vehicle facilitates their unscrewing. In the case of the action marked (2), we are dealing with a situation where the action does not require to be included in a formal procedure. However, the omission of action (2) will result in an abnormal completion of the procedure. 


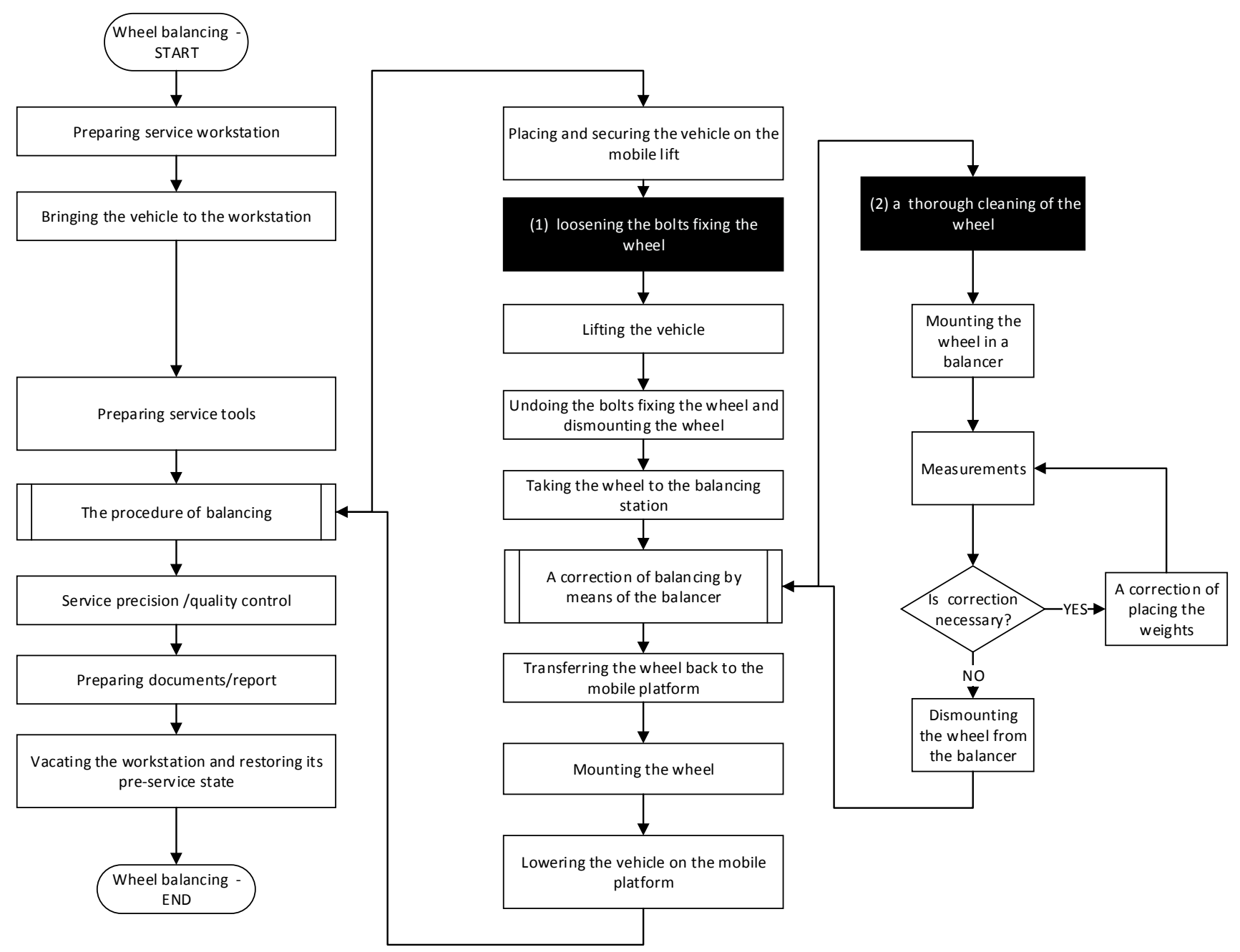

Figure 2. The servicing procedure including actions undertaken due to tacit knowledge

According to the accepted stages in the TKT-SDM model, in step (1), the identification of the sources of tacit knowledge: sources of tacit knowledge have been defined (Dudek, Patalas-Maliszewska, 2016) the precise source in the analyzed service department:

- technician $-\mathrm{w}_{\mathrm{u} 1}$

- operations manager / work organizer - $\mathrm{w}_{\mathrm{u} 4}$

- user - $\mathrm{W}_{\mathrm{u} 5.2}$

- design department worker - $\mathrm{w}_{\mathrm{u} 7.2}$

- production worker - $\mathrm{w}_{\mathrm{u} 7.3}$

- component supplier's worker - $\mathrm{w}_{\mathrm{u} 7.4}$

- user of the product - $\mathrm{w}_{\mathrm{u} 12}$

Then, according to step (2), the acquisition of tacit knowledge of the TKT-SDM model, an attempt has been made to find a solution supporting the acquisition of significant tacit knowledge through detecting instances of individual servicing actions. We obtained tacit knowledge from technician - wul using audio-video recordings. The basis for the carried out experiments is the utterance of an expert, whose task is to report the ongoing activities.

As part of stage (3), introduction of a formalized record of tacit knowledge of the TKT-SDM model, an ASR solution has been used to convert the recorded voice commentary to a text form. The resulting text will be tested in the next step by means of statistical language analysis to extract its most important features. In addition, to strengthen the credibility of this process, the technique of detecting objects in an image will be used. If, in the analyzed fragment, it will be possible to detect the objects referred to in the recognized text, that will be an important factor supporting the final classification of the analyzed fragment. 
To present the assumptions of the proposed model in practice, an experiment was conducted based on 17 audio-video recordings of service procedures relating to vehicle braking systems. For the purposes of the experiment, different length recordings have been selected, in which various service procedures have been recorded, whose common element was, however, the operation of disassembling and subsequent reassembling of brake pads.

In order to receive a verbal record of the registered utterances, we used the Google Speech API software, and then conducted its statistical analysis to define the characteristics of the test set of recordings. The documents obtained on the basis of the recordings have been analyzed assuming the omission of conjunctions, prepositions, and pronouns, as well as inflection forms.

As a result, we obtained unigrams for the most common words for the entire set of documents and frequency distributions of their manifestations in individual recordings.
A detailed description of the experiment and its results are shown in Chapter 4.

\section{An example of the implementation of a TKT-SDMC model}

The process of tacit knowledge transformation in a TKT-SDMC model is based on a technique of ASR. Tacit knowledge has been obtained from the employees of the service department of a production company through the use of the methods of teacher observation and audit knowledge and audio-video recordings. During the recording, a service technician, as a source of tacit knowledge, describes in words all the actions he performs in the execution of the task. To verify the applicability of this approach, an attempt has been made to recognize the text from the recordings and from statistical analysis of obtained documents. To objectify the process, 17 recordings have been selected, which documented the course of various service procedures on the vehicle suspension system.

Table 1. Instances of the selected service operations in the analyzed recordings

\begin{tabular}{|l|l|l|l|l|l|l|l|l|l|l|l|l|l|l|l|l|l|}
\hline $\begin{array}{l}\text { Film number / } \\
\text { Service operation }\end{array}$ & $\mathbf{1}$ & $\mathbf{2}$ & $\mathbf{3}$ & $\mathbf{4}$ & $\mathbf{5}$ & $\mathbf{6}$ & $\mathbf{7}$ & $\mathbf{8}$ & $\mathbf{9}$ & $\mathbf{1 0}$ & $\mathbf{1 1}$ & $\mathbf{1 2}$ & $\mathbf{1 3}$ & $\mathbf{1 4}$ & $\mathbf{1 5}$ & $\mathbf{1 6}$ & $\mathbf{1 7}$ \\
\hline $\begin{array}{l}\text { Disassembling } \\
\text { brake pads }\end{array}$ & $\mathrm{X}$ & $\mathrm{X}$ & $\mathrm{X}$ & $\mathrm{X}$ & $\mathrm{X}$ & $\mathrm{X}$ & $\mathrm{X}$ & $\mathrm{X}$ & $\mathrm{X}$ & $\mathrm{X}$ & $\mathrm{X}$ & $\mathrm{X}$ & $\mathrm{X}$ & $\mathrm{X}$ & $\mathrm{X}$ & $\mathrm{X}$ & \\
\hline $\begin{array}{l}\text { Disassembling } \\
\text { brake calipers }\end{array}$ & $\mathrm{X}$ & & & & & & & $\mathrm{X}$ & $\mathrm{X}$ & $\mathrm{X}$ & $\mathrm{X}$ & $\mathrm{X}$ & $\mathrm{X}$ & $\mathrm{X}$ & $\mathrm{X}$ & $\mathrm{X}$ & \\
\hline $\begin{array}{l}\text { Disassembling } \\
\text { brake discs }\end{array}$ & & & & & & & & $\mathrm{X}$ & $\mathrm{X}$ & $\mathrm{X}$ & $\mathrm{X}$ & $\mathrm{X}$ & $\mathrm{X}$ & $\mathrm{X}$ & $\mathrm{X}$ & $\mathrm{X}$ & $\mathrm{X}$ \\
\hline $\begin{array}{l}\text { Disassembling } \\
\text { the hub and bear- } \\
\text { ings }\end{array}$ & & & & & & & & $\mathrm{X}$ & & & & & & & & & \\
\hline $\begin{array}{l}\text { Hub and bearing } \\
\text { assembly }\end{array}$ & & & & & & & & $\mathrm{X}$ & & & & & & & & & \\
\hline $\begin{array}{l}\text { Installation } \\
\text { of brake disc }\end{array}$ & & & & & & & & & & & & & & & & &
\end{tabular}


For further investigation, the following tasks in the service department have been selected (marked by numbers from 1 to 17 ):

- regeneration of brake calipers - film 1 ,

- replacement of front brake pads - films 2 to 4 ,

- replacement of rear brake pads - films 5 to 7 ,

- replacement of wheel bearings - film 8 ,

- replacement of brake discs and brake pads - films 9 to 17 .

Table 1 shows the service operations that have been presented in various recordings ( $\mathrm{X}$ is an instance of a service operation in the selected recording).

As shown in Table 1, each represented service procedure included the removal of brake pads, regard- less of whether it was its direct aim or merely an indirect activity.

Table 2 shows the classification of the obtained recordings based on the original criteria: $\mathrm{k} 1$ - the technical quality of the voice recording (too quiet / loud / not clear - 1, clear and clean - 5), k2 - interference and background noise (wind noise, voices and background sounds: 1 - very clear, 5 - not significant), k3 - noise during utterances (1 - statement distorted by noises made by tools, 3 - interrupted, but not distorted utterance), $\mathrm{k} 4$ - the process of formulating statements (a subjective scale: 1 - language primitivism, 5 - a linguistically correct, precise statement), $\mathrm{k} 5$ - the involvement of the technician (a subjective scale: 1 - not trying, 5 - full involvement in the transfer of knowledge).

Table 2. Classification of the obtained recordings

\begin{tabular}{|c|c|c|c|c|c|c|c|c|c|c|c|c|c|c|c|c|c|}
\hline $\begin{array}{l}\text { Film number / } \\
\text { criterion number }\end{array}$ & 1 & 2 & 3 & 4 & 5 & 6 & 7 & 8 & 9 & 10 & 11 & 12 & 13 & 14 & 15 & 16 & 17 \\
\hline k1 & 5 & 3 & 4 & 4 & 3 & 4 & 2 & 3 & 3 & 4 & 2 & 3 & 5 & 2 & 2 & 3 & 5 \\
\hline k2 & 5 & 5 & 5 & 4 & 2 & 4 & 3 & 2 & 2 & 2 & 1 & 2 & 5 & 2 & 2 & 2 & 5 \\
\hline k3 & 2 & 5 & 5 & 4 & 3 & 4 & 3 & 1 & 3 & 4 & 2 & 3 & 5 & 2 & 2 & 3 & 3 \\
\hline k4 & 3 & 5 & 4 & 4 & 3 & 3 & 3 & 3 & 3 & 3 & 2 & 3 & 3 & 3 & 3 & 3 & 4 \\
\hline k5 & 4 & 5 & 4 & 5 & 5 & 4 & 3 & 3 & 4 & 3 & 2 & 3 & 4 & 4 & 4 & 3 & 5 \\
\hline sum & 19 & 23 & 22 & 21 & 16 & 19 & 14 & 12 & 15 & 16 & 9 & 14 & 22 & 13 & 13 & 14 & 22 \\
\hline
\end{tabular}

The aforementioned recordings have been processed using automatic recognition technology in order to obtain verbal recordings, which have been subsequently statistically processed to extract their characteristics. For the purpose of extracting the verbal notation from the video recordings, Google Speech API software has been used. It is one of the few universal solutions with acceptable performance in the area of the Polish language. Table 3 shows the numbers of recognized words in individual recordings in relation to their length and the cumulative quality ratios shown in Table 2.

Table 3 shows that neither the length of the recording nor its quality factor do not directly affect the number of recognized words. However, from the two characteristics, the quality factor of the ana- lyzed material plays a more significant role. In the presented model, acquiring knowledge in the service department is a key problem, since, in a service station practice, the quality of the audio recording and the amount of interference (noise) is changing very rapidly.

The documents obtained in this way have been put under a statistical, shallow analysis of the text, in order to acquire their vector representations. For its purposes, a dedicated assistant application has been prepared. The core of this model is the representation of documents through vectors, where for each word or string of words found in the analyzed set of documents, a measure of significance is indicated. In most cases, that measure is the frequency of occurrence. 
Table 3. Numbers of recognized words in individual recordings

\begin{tabular}{|c|c|c|c|}
\hline $\begin{array}{c}\text { Film } \\
\text { number }\end{array}$ & $\begin{array}{c}\text { Length } \\
\text { of the recording }\end{array}$ & $\begin{array}{c}\text { Cumulative } \\
\text { quality ratio }\end{array}$ & $\begin{array}{c}\text { Number } \\
\text { of words }\end{array}$ \\
\hline 1 & $22: 25$ & 19 & 1679 \\
\hline 2 & $03: 14$ & 23 & 237 \\
\hline 3 & $02: 21$ & 22 & 110 \\
\hline 4 & $07: 22$ & 21 & 341 \\
\hline 5 & $23: 56$ & 16 & 1650 \\
\hline 6 & $06: 00$ & 19 & 325 \\
\hline 7 & $08: 12$ & 14 & 303 \\
\hline 8 & $15: 20$ & 12 & 30 \\
\hline 9 & $44: 19$ & 15 & 818 \\
\hline 10 & $16: 55$ & 16 & 776 \\
\hline 11 & $15: 34$ & 9 & 6 \\
\hline 12 & $12: 31$ & 14 & 87 \\
\hline 13 & $12: 56$ & 22 & 414 \\
\hline 14 & $13: 54$ & 13 & 607 \\
\hline 15 & $23: 38$ & 13 & 510 \\
\hline 16 & $11: 33$ & 14 & 1001 \\
\hline 17 & $16: 57$ & 22 & \\
\hline
\end{tabular}

An analysis of the frequency of occurrence of particular words in the analyzed set of documents, including all 3,070 that have been recognized, has been conducted. Table 4 summarizes the frequencies of the most common words.

Table 4. The most common and least common words in the analyzed set of documents

\begin{tabular}{|c|l|c|c|l|c|c|l|c|c|l|c|}
\hline no. & word & number & no. & word & number & no. & word & number & no. & word & number \\
\hline 1 & to & 345 & 8 & jest & 139 & 15 & żeby & 71 & 22 & tego & 52 \\
\hline 2 & nie & 243 & 9 & do & 128 & 16 & klocki & 67 & 23 & prostu & 49 \\
\hline 3 & i & 204 & 10 & jak & 121 & 17 & co & 66 & 24 & trzeba & 49 \\
\hline 4 & na & 195 & 11 & z & 118 & 18 & będzie & 66 & 25 & ten & 45 \\
\hline 5 & się & 187 & 12 & tutaj & 100 & 19 & teraz & 64 & 26 & ale & 44 \\
\hline 6 & w & 140 & 13 & po & 86 & 20 & sobie & 62 & 27 & tym & 43 \\
\hline 7 & tak & 139 & 14 & że & 73 & 21 & wszystko & 61 & 28 & no & 42 \\
\hline
\end{tabular}

As shown in Table 4, a statistical analysis of documents in full original wording does not produce representative results due to the nature of the Polish language - rich with prepositions, conjunctions, and pronouns, which carry no useful information. Therefore, in the analysis, the so-called stop lists containing these parts of speech for the Polish lan- guage were included. At the same stage, the analysis excluded words shorter than four characters, treating them as unimportant or as a result of errors in the operation of ASR.

Given these assumptions, the set was limited to 2,632 words. The results of the renewed analysis are shown in Table 5. 
Table 5. The most common words without prepositions, conjunctions, pronouns, and words shorter than four characters

\begin{tabular}{|c|l|c|c|l|c|c|l|c|l|l|c|}
\hline no. & word & num. & no. & word & num. & no. & word & num. & no. & word & num. \\
\hline 1 & klocki & 67 & 8 & jeszcze & 40 & 15 & wygląda & 26 & 22 & musimy & 18 \\
\hline 2 & będzie & 66 & 9 & zacisk & 32 & 16 & bardzo & 26 & 23 & zrobić & 18 \\
\hline 3 & teraz & 64 & 10 & samochód & 32 & 17 & oczywiście & 21 & 24 & śruby & 17 \\
\hline 4 & sobie & 62 & 11 & można & 29 & 18 & strony & 20 & 25 & sposób & 16 \\
\hline 5 & prostu & 49 & 12 & klocków & 29 & 19 & możemy & 19 & 26 & hamulcowe & 16 \\
\hline 6 & trzeba & 47 & 13 & zacisku & 27 & 20 & takie & 19 & 27 & potem & 16 \\
\hline 7 & tylko & 41 & 14 & widać & 27 & 21 & thoczek & 19 & 28 & trochę & 16 \\
\hline
\end{tabular}

Further analysis of the results shows another Polishspecific problem with NLP solutions related to inflection. As a result, one word is represented by a few grammatical forms, which disturbs the frequency analysis. Therefore, the application created for this study has been supplemented by a dictionary of Polish language along with the inflection forms for individual words. This dictionary was built on the basis of a set developed within Dictionary SJP.PL project (Słownik języka polskiego, 2016). The dictionary contains 189,573 words and 3,562,734 corresponding inflection forms. Table 6 summarizes the results of the numerousness analysis of individual forms of basic words, with the same as in Table 5 selection criteria. Thanks to the dictionary, the range of different basic forms has been limited to 1,743 words.

Table 6. Most frequent basic forms of words

\begin{tabular}{|c|l|c|c|l|c|c|l|c|c|c|c|}
\hline no. & word & num. & no. & word & num. & no. & word & num. & no. & word & num. \\
\hline 1 & klocek & 121 & 8 & musieć & 42 & 15 & wyglądać & 36 & 22 & tarcza & 27 \\
\hline 2 & siebie & 67 & 9 & tarcze & 41 & 16 & śruba & 35 & 23 & widać & 27 \\
\hline 3 & zacisk & 67 & 10 & tylko & 41 & 17 & wyczyścić & 34 & 24 & bardzo & 26 \\
\hline 4 & teraz & 64 & 11 & hamulcowy & 40 & 18 & zrobić & 32 & 25 & miejsce & 25 \\
\hline 5 & samochód & 54 & 12 & jeszcze & 40 & 19 & hamulec & 30 & 26 & dobro & 24 \\
\hline 6 & prostu & 49 & 13 & strona & 39 & 20 & tenże & 29 & 27 & tłoczek & 24 \\
\hline 7 & trzeba & 47 & 14 & prowadnica & 36 & 21 & możny & 29 & 28 & wymiana & 23 \\
\hline
\end{tabular}

For the words with the highest incidence shown in Table 6, we delineated unigrams of occurrence in each studied file. A unigram includes the numbers of instances of chosen words in each of the analyzed documents. The graphical representation of the unigram for the analyzed set of documents is shown in Fig. 3.

The unigram presented in Fig. 3 allows to determine the level of significance (based on the numerousness of instances) of individual words in the analyzed set of documents, and thus make an attempt to determine a model of a document specific for the presented issue, assuming that the significance distribution of the words in all the documents is similar.
In the next stage of the analysis, we determined the distributions of the frequency of most numerously represented word occurrences in individual documents, which have been presented in Fig. 4 and 5 . In both cases, we used intervals with a width of 10 , which means one-tenth of all the words in a document. The study of the results fails to determine unambiguously the characteristics of the analyzed set of documents.

While for the word "hamulcowy," a regularity can be observed that in most documents it dominates in one interval of the length of the document, in the case of the word "klocek," such regularity is impossible to determine. 
This is the consequence of the distribution of the content in individual recordings. On the one hand, they are diverse in terms of length, on the other in terms of "the approach to the presentation" of knowledge by specialists, which can be divided into two types:

- I say what I am going to show $\rightarrow$ I show $\rightarrow$ I summarize,

- I say and show $\rightarrow$ I say and show.

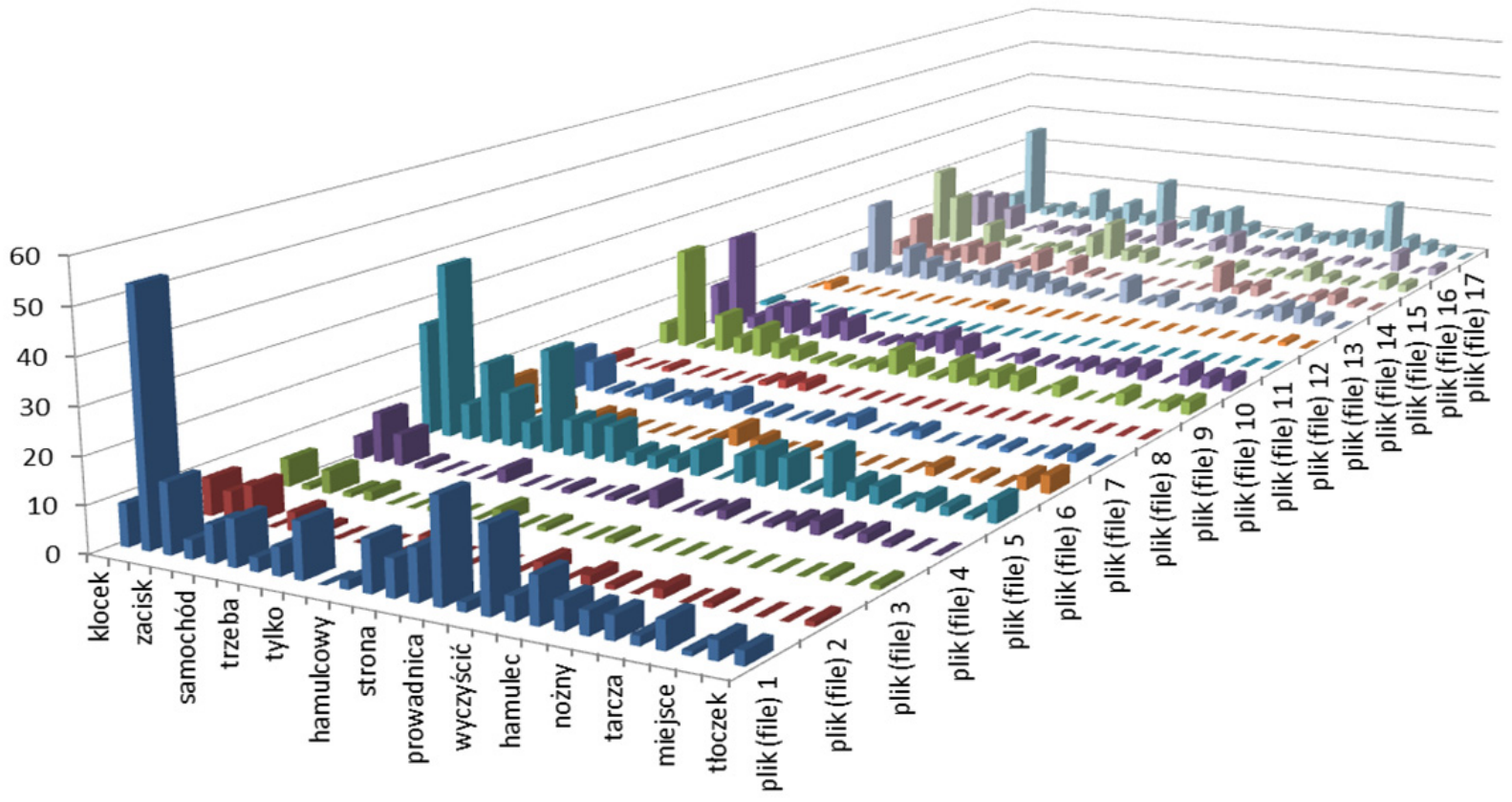

Figure 3. Graphical representation of the unigram for words with the highest occurrence

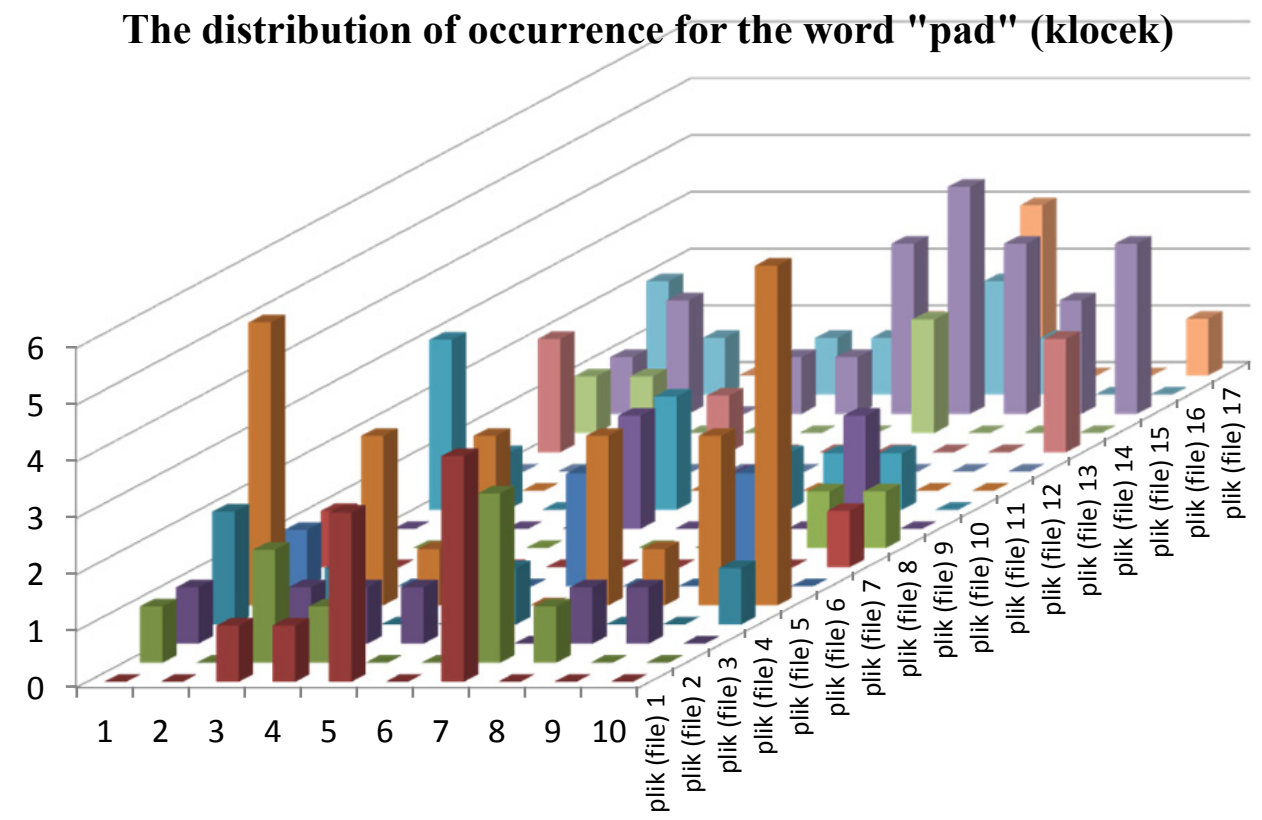

Figure 4. The distribution of occurrence for the word "pad" (klocek) 


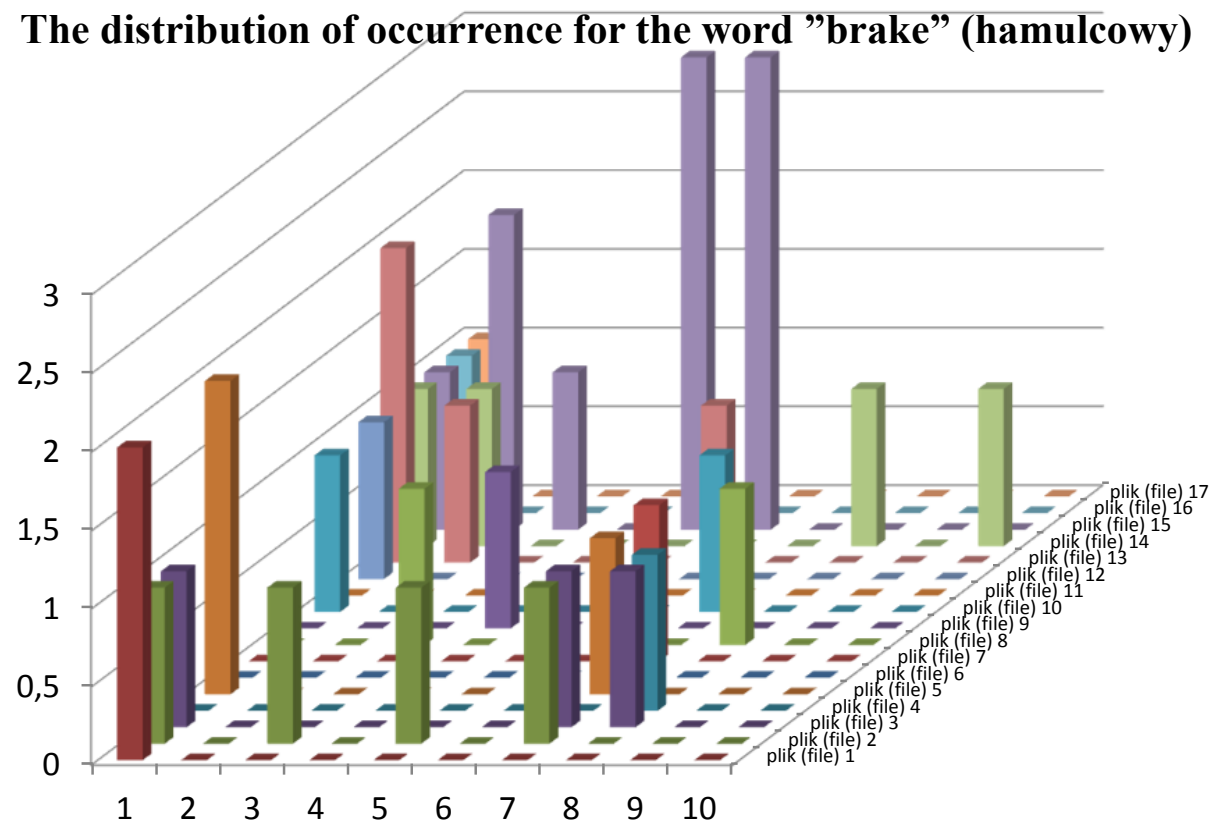

Figure 5. The distribution of occurrence for the word "brake" (hamulcowy)

Based on the acquired unigrams, further analyses will deal with defining the set of words/sentences describing a given service operation performed by an employee, which make up the sought-after formal procedure in the service department of a production company.

Based on the occurrence distribution of single words or groups, it is possible to preliminarily indicate the sections relating to individual service operations (implementation of phase (4) - the classification of the acquired knowledge in TKT-SDMC model). Subsequently, the acquired fragments of the procedures should be accepted by an expert in a given department of the company.

\section{Conclusions}

The presented model of the transformation of tacit knowledge into an explicit form in the service department of the production company, the TKTSDMC model, is based on the concept of using the mechanism of ASR followed by an extraction of characteristics of the acquired recordings, aided by the detection of objects in video recordings. A review of up-to-date methods of acquiring knowledge has been presented, and the model of acquiring significant tacit knowledge for individu- al service operations making up the service procedures has been proposed. The results of a research experiment, consisting in processing 17 selected recordings of various service procedures through the ASR mechanism have been shown, followed by a statistical analysis of the collected set of documents. The analysis of the results allows to claim that the attempt to build a standard model for the recordings of everyday workshop practice, merely on the basis of a simple statistical analysis, is impossible. In further study, it is planned to carry out a thorough examination of the impact of noise on the effectiveness of speech recognition and an in-depth analysis of thus obtained documents based on the study of the meaning of words and phrases, in order to obtain a formal procedure on the grounds of tacit knowledge for the service department in a manufacturing company.

\section{References}

[1] Ali, N., Peebles, D., 2013. Reactivity effects of concurrent verbalisation during a graph comprehension task. In: The annual meeting of the Cognitive Science Society. COGSCI 2013, pp. 1720 - 1725.

[2] Allal-Chérif, O., Bidan, M. and Makhlouf, M., 2016. Using serious games to manage 
knowledge and competencies: The seven-step development process. Information Systems Frontiers, pp.1-11.

[3] Antonova, A., Stefanov, K., 2011. Applied Cognitive Task Analysis in the Context of Serious Games Development. In: D. Dicheva, ed., et al., 2011. Software, Services \& Semantic Technologies. AISC 101, Springer-Verlag Berlin, pp.175-182.

[4] Boiman, O., Shechtman, E. and Irani, M., 2008. In defense of nearest-neighbor based image classification, Computer Vision and Pattern Recognition. In: CVPR 2008, IEEE Conference on, IEEE.

[5] Boose, J. H., 1989. A survey of knowledge acquisition techniques and tools. Knowledge Acquisition, 1 (1), pp.3-37.

[6] Bosch, A., Zisserman, A., Munoz, X., 2007. Image classification using random forests and ferns. In: Computer Vision 2007, ICCV 2007, IEEE $11^{\text {th }}$ International Conference on IEEE.

[7] Boyle, E.A., Hainey, T., Connolly, T. M., Gray, G., Earp, J., Ott, M., Lim, T., Ninaus, M., Ribeiro, C., Pereira, J., 2016. An update to the systematic literature review of empirical evidence of the impacts and outcomes of computer games and serious games. Computers \& Education, 94, pp.178-192.

[8] Cisco, 2012. 15-Minute Guide to Pulse Video Analytics. Cisco and/or its affiliates.

[9] Christoudias, C. M., Urtasun, R., Darrell, T., 2008. Unsupervised feature selection via distributed coding for multi-view object recognition. In: Computer Vision and Pattern Recognition, CVPR 2008, Conference on IEEE.

[10] Davis, K. H., Biddulph, R. and Balashek, S., 1952. Automatic Recognition of Spoken Digits. In: Acoustical Society of America.

[11] Dudek, A., Patalas-Maliszewska, J., 2016. IT tool for knowledge management support in the service department in the manufacturing company - a case study. In: R. Knosala, ed. Innovation in Management and Production Engineering. Oficyna Wydawnicza Polskiego Towarzystwa Zarządzania Produkcja, Vol 2, pp.35-46.

[12] Dzwiarek, M., Luczak, A., 2008. Application prospects of the augmented reality technology for improving safety of machine operators. In: INTECH Open Access Publisher.

[13] Faust, B., 2007. Implementation of tacit knowledge preservation and transfer methods. In: International Conference on Knowledge Management in Nuclear Facilities. Vienna, Austria.

[14] Furui, S., 2005. 50 Years of Progress in Speech and Speaker Recognition Research. ECTI transactions on computer and information technology, 1(2).

[15] Gałaj, J., Oleksy, M., 2013. Przegląd hybrydowych modeli pożaru (Overview of the hybrid models of fire). Bezpieczeństwo $i$ Technika Pożarnicza (Safety \& Fire Technique), 32 (4).

[16] Gonzalez-Franco, M., Cermeron, J., Li, K., Pizarro, R., Thorn, J., Hannah, P. and BermellGarcia, P., 2016. Immersive Augmented Reality Training for Complex Manufacturing Scenarios. arXiv preprint arXiv:1602.01944.

[17] Gomółka, Z., 2008. Identyfikacja mówcy z wykorzystaniem współczynników predykcji liniowej (The Mechanism of Linear Pprediction in the Task Speaker Identification). Technical News, (2008/1), pp.63-66.

[18] Gouet-Brunet, V., Lameyre B., 2008. Object recognition and segmentation in videos by connecting heterogeneous visual features. Computer Vision and Image Understanding, pp.86-109.

[19] Gourova, E., Toteva, K. and Todorova Y., 2012. Audit of knowledge flows and critical business processes. In: Proceedings of the 17th European Conference on Pat- tern Languages of Programs (EuroPLoP'12). New York, NY, pp.1-10.

[20] Goth, G., 2016. Deep or shallow, NLP is breaking out. In: Communications of the ACM 59.3, pp.13-16.

[21] Govaerts, M.J.B., Van de Wiel, M. W.J., Schuwirth, L.W.T., Van der Vleuten, C.P.M., Muijtjens, A.M.M., 2012. Workplace-based assessment: raters' performance theories and constructs. Advances in Health Sciences Education Theory and Practice, 18(3), pp.375-396.

[22] Grad, L., 2007. Kompresja stratna dźwięku. In: P. Sienkiewicz, ed., Zeszyt naukowy nr 2 (Scientific notebook number 2). Warsaw: Warszawska Wyższa Szkoła Informatyki (Warsaw School of Computer Science), pp.39-58. 
[23] Hernes, M., Maleszka, M., Nguyen, N.T., Bytniewski, A., 2015. The automatic summarization of text documents in the Cognitive Integrated Management Information System. In: Computer Science and Information Systems (FedCSIS), Federated Conference on IEEE, pp.1387-1396.

[24] Hinton, G., Deng L., Dong, Yu., Dahl, G.E., Abdel-rahman, M., Jaitly, N., Andrew, S., Vanhoucke, V., Nguyen, P., Sainath, T.N. and Kingsbury, B., 2012. Deep Neural Networks for Acoustic Modeling in Speech Recogniction. IEEE Signal processing magazine, pp.82-97.

[25] Hoffman, R., Shadbolt, N.R., Burton, M.A., Klein, G., 1995. Elicting Knowledge from Experts: A methodological Analysis. Organization behavior and human decizion processes, 62 (2), pp.129-158.

[26] Itakura, F., 1975. Minimum prediction residual applied to speech recognition. In: IEEE Trans. Acoustics, Speech, Signal Proc. ASSP-23 (1), pp.67-72.

[27] Jelinek, F., 1985. The development of an experimental discrete dictation recognizer. Proceedings of the IEEE, 73(11), pp.1616-1624.

[28] Kambhatla, N., Zitouni, I., 2013. Systems and methods for automatic semantic role labeling of high morphological text for natural language processing applications. U.S. Patent No. $8,527,262$.

[29] Karkula, M., 2014. Badania symulacyjne procesów transportowych realizowanych w obiektach logistycznych (Simulation Studies of Transport Processes in Logistics Facilities). Logistyka, 4 (2), pp.1971-1980.

[30] Kale, R., Bhabad, S.S., 2015. Speech Recognition of Articulatory Handicapped People By Using LPC. International Journal Of Scientific Research And Education, 3 (02), pp.2893-2899.

[31] Kompanec, L., Kubanek, M., 2002. Specyfika wykorzystania ukrytych modeli markowa przy rozpoznawaniu mowy polskiej (The specificity of the use of hidden Markov models using speech recognition Polish). Informatyka Teoretyczna i Stosowana, 2 (3), pp.45-56.

[32] Kwasek, A., 2016. IT Tools Used in the Management of New Model of Economy, the Knowledge-Based Economy. Kwartalnik Naukowy Uczelni Vistula, 1 (47), pp.94-108.
[33] Lee, T., Soatto, S., 2011. Video-based descriptors for object recognition. Image and $\mathrm{Vi}$ sion Computing, 29 (10), pp.639-652.

[34] Lazebnik, S., Schmid, C. and Ponce, J., 2006. Beyond bags of features: Spatial pyramid matching for recognizing natural scene categories. In: Computer Vision and Pattern Recognition. 2006 IEEE Computer Society Conference.

[35] Lemke, J., 2012. Analyzing Verbal Data: Principles, Methods, and Problems. In: Springer International Handbooks of Education. The Netherlands: Springer, pp.1471-1484.

[36] Leśnik, M., Dobrowolski D., 2016. Zarządzanie wiedzą jako proces. In: R. Knosala ed., 2016. Innowacje w zarządzaniu i inżynierii produkcji. Opole: Wyd. Oficyna Wydawnicza Polskiego Towarzystwa Zarządzania Produkcja, pp.85-96.

[37] Li, F.-F., Perona, P., 2005. A bayesian hierarchical model for learning natural scene categories. In: Computer Vision and Pattern Recognition, CVPR 2005, IEEE Computer Society Conference.

[38] Lin, T.J., Duh, H.B.L., Li, N., Wang, H.Y. and Tsai C.C., 2013. An investigation of learners' collaborative knowledge construction performances and behavior patterns in an augmented reality simulation system. Computers \& Education, 68, pp.314-321.

[39] Lundy, J., 2016. Hot Vendors in Enterprise Video. Aragon Research, 12.

[40] Mermon, A., 2011. Sieci Bayesa w rozpoznawaniu mowy (Bayes networks used in application to speech signal recognition). Pomiary automatyka Robotyka, 12/2011.

[41] Mietła, A., Iwaniec M., 2010. Praktyczne aspekty wykorzystywania systemów rozpoznawania mowy opartych na HMM. Modelowanie Inżynierskie - Polskie Towarzystwo Mechaniki Teoretycznej i Stosowanej, 9 (40), pp.171 - 178.

[42] Nonaka, I., Takeuchi H., 2000. Kreowanie wiedzy $w$ organizacji (Creating knowledge in the organization). Warszawa: Poltext.

[43] Pa, N. C., Taheri, L. and Abdullah, R., 2012. A Survey on Approaches in Knowledge Audit in Organization. Asian Transaction on Computers, 2 (5), pp.1-8.

[44] Pawlaczyk, L., Bosky, P., 2009. Skrybot A System for Automatic Speech Recognition of Polish Language. Man-Machine Interactions 
in Advances in Intelligent and Soft Computing, 59, pp.381-387.

[45] Piotrowska, A., 2012. Wiedza jawna i niejawna jako zasób decyzyjny $w$ zarzqdzaniu personelem (Explicit and implicit knowledge as a resource decision-making in personnel management). In: A. Grzegorczyk ed., Procesy decyzyjne $w$ warunkach niepewności. Warszawa: Wyższa Szkoła Promocji, pp.79-95.

[46] Przepiórkowski, A., Bańko, M., Górski R. and Lewnadowska-Tomaszczyk B., 2012. Narodowy Korpus Języka Polskiego (National Corpus of Polish Language). Warszawa: Wydawnictwo Naukowe PWN.

[47] Przybysz, P., Kasprzak, W., 2012. Rozpoznawanie zdan $w$ sygnale mowy z wykorzystaniem modelu HMM (Recognition of sentences in the speech signal using HMM model). Raport IAiIS PW Nr 12-05, Warszawa.

[48] Ptocoki, A., Łukasik, P., 2014. Wybrane metody komunikacji ukierunkowane na wykorzystanie wiedzy $w$ organizacji (Selected methods of communication directed to the use of knowledge in the organization). In: A. Stabryła, S. Wawak, ed., 2014. Problemy zarzqdzania organizacjami $w$ społeczeństwie informacyjnym. Kraków: Mfiles.

[49] Rabiner, L., Juang, B. H., 1993. Fundamentals of speech recognition. New York: Prentice Hall, Englewood Cliffs.

[50] Ragsdell, G., Probets S. and Ahmed G., 2013. Knowledge audit: findings from a case study in the energy sector. In: 14th European Conference on Knowledge Management. Kaunus University of Technology, Lithuania, 5-6 September 2013, pp.584-593.

[51] Salmon, K., Pipe, M. E., Malloy, A. and Mackay, K., 2012. Do Non-Verbal Aids Increase the Effectiveness of 'Best Practice' Verbal Interview Techniques? An Experimental Study. Applied Cognitive Psychology, 26 (3), pp.370-380.

[52] Seager, W., Ruskov, M., Sasse, M.A. and Oliveira, M., 2011, Eliciting and modelling expertise for serious games in project management. Entertainment Computing, pp.75-80.

[53] Stownik języka polskiego (Polish dictionary). [online] Available at: http://www.sjp.pl [Accessed: 10 June 2016].
[54] Shomali, A., Kapusta, M. and Gajer, M., 1999. Zastosowanie niejawnych modeli Makowa w systemach automatycznego rozpoznawania mowy (The use of HMM in automatic speech recognition). Elektrotechnika $i$ Elektronika, pp.89-99.

[55] Unikkon Integral Sp. z o.o., 2013. O MagicScribe. [online] Available at: http://magicsc ribe.pl/index.php/o-magicscribe.html [Accessed: 13 May 2016].

[56] Yang, J., Yu K., Gong Y., Huang, T., 2009. Linear spatial pyramid matching using sparse coding for image classification. In: Computer Vision and Pattern Recognition Conference.

[57] Yusoff, N.M., Salim, S.S., 2012. Investigating cognitive task difficulties and expert skills in eLearning storyboards using a cognitive task analysis technique. Computers \& Education, (58), pp.652-665.

[58] Wyrębek, H., 2013. Zarządzanie wiedzą w organizacjach zhierarchizowanych (Knowledge management in hierarchical organizations), Zeszyty Naukowe Uniwersytetu Przyrodniczo-Humanistycznego, 96, pp.51-53.

[59] Yang, J., Yu, K., Gong, Y. and Huang, T., 2009. Linear spatial pyramid matching using sparse coding for image classification. In: Computer Vision and Pattern Recognition Conference.

[60] Yang, Y., Liu, X., 1998. A re-examination of text categorization methods. In: ACM SIGIR Conference on Research and Development in Information Retrieval. New York.

[61] Zieliński, M., 2015. Personalne warunki tworzenia inteligentnej organizacji (Personnel conditions of creation of intelligent organization). Scientific Papers of Silesian University of Technology, 86 (1946).

[62] Ziółkowski, S., 2015. Organizacje przyszłości. Wyzwania dla zarządzania wiedzą w sieciach (Organizations future. Challenges for knowledge management networks). Zeszyty Naukowe Uniwersytetu Ekonomicznego w Katowicach, 224.

[63] Zweig, G., Russell, S., 1998. Speech Recognition with Dynamic Bayesian Networks. AAAI-98 Proceedings.

[64] Żelazko, P., Ziółko, B., Jadczyk, T. and Skurzok, D., 2015. AGH corpus of Polish speech. Lang Resources \& Evaluation, early access. 